\title{
Impact of Erlotinib and Metformin Administration on Pharmacokinetics of Meloxicam in SCID Mice
}

\author{
S.D. Patel ${ }^{1 *}$, U.D. Patel $^{2}$, K.A. Sadariya ${ }^{3}$, S.K. Bhavsar ${ }^{3}$ and A.M. Thaker $^{3}$ \\ ${ }^{1}$ Zydus Research Centre, Cadila Healthcare Ltd., Ahmedabad, India \\ ${ }^{2}$ College of Veterinary Science and Animal Husbandry, Junagadh \\ Agricultural University, Junagadh, India \\ ${ }^{3}$ College of Veterinary Science and Animal Husbandry, Anand \\ Agricultural University, Anand, India \\ *Corresponding author
}

\begin{tabular}{|c|c|}
\hline & $\mathbf{B}$ \\
\hline & \multirow{5}{*}{$\begin{array}{l}\text { Pharmacokinetics of meloxicam was studied following its single dose intraperitoneal } \\
\text { administration alone and administered with erlotinib and/or metformin in SCID mice. The } \\
\text { plasma concentration of meloxicam was assayed by LC-MS/MS. Following administration } \\
\text { of meloxicam as single drug in male SCID mice, the mean values of observed peak plasma } \\
\text { drug concentration (Cmax), time of maximum concentration (Tmax), area under plasma } \\
\left.\text { drug concentration-time curve (AUC } \mathrm{C}_{0-\infty}\right) \text {, volume of distribution }(\mathrm{Vz}) \text {, half-life }(\mathrm{t} \mathrm{t} / \mathrm{s}) \text { and } \\
\text { total body clearance }(\mathrm{Cl}) \text { were } 45715.22 \pm 3343.07 \mathrm{ng} / \mathrm{mL}, 0.40 \pm 0.09 \mathrm{~h}, 123999.94 \pm \\
4181.79 \mathrm{ng} . \mathrm{h} / \mathrm{mL}, 873.90 \pm 59.61 \mathrm{ml}, 3.79 \pm 0.34 \mathrm{~h} \text { and } 162.24 \pm 5.67 \mathrm{ml} / \mathrm{h} \text {, respectively. } \\
\text { When erlotinib and/or metformin were administered with meloxicam in SCID mice, } \\
\text { significant alterationin pharmacokinetic parameters of meloxicam were observed. Thus, } \\
\text { pharmacovigilance should be followed for the concomitant administration of these drugs } \\
\text { for prolong period. However, clinical pharmacokinetic interaction of these drugs in human } \\
\text { needs to be evaluated. }\end{array}$} \\
\hline Keywords & \\
\hline & \\
\hline & \\
\hline & \\
\hline
\end{tabular}

\section{Introduction}

Non-steroidal anti-inflammatory drugs (NSAIDs) have been used for various disease conditions in human and animals. During the last decade, many studies have shown that NSAIDs may have potential as a chemopreventive for cancer. The use of NSAIDs to prevent colorectal cancer, as well as in various human clinical cancer cases have also been documented (Giardiello, 1996; Thun, 1996; Steinbach et al., 2000; Husain et al., 2002). Expression of COX-2 is upregulated in both human cancers and chemically induced rodent and murine cancers (Abou-Issa et al., 2001; Ristimaki et al., 2001; Suzuki et al., 2009). Inhibitors of COX-2 exhibit an important role as chemopreventive in cancers including non-small cell lung cancer (NSCLC) (Abou-Issa et al., 2001; Ramalingam and Belani, 2004). The inhibitors of COX-2 may have beneficial effect by several means as induction of apoptosis, inhibition of angiogenesis, and decreased 
invasiveness and metastatic potential. Meloxicam is non-steroidal anti-inflammatory drug (NSAID) of the oxicam class, which produces anti-inflammatory, anti-exudative, analgesic and antipyretic effects by inhibition of prostaglandin synthesis and cyclooxygenase (Friton et al., 2003; Hirsch et al., 2003; Papatsas et al., 2004). Pharmacokinetic studies of meloxicam have previously been conducted in mice (Goldman et al., 1998), rats (AguilarMariscal et al., 2007; Habashi and Jamali, 2008), rabbits (Turner et al., 2006, Carpenter et al., 2009), dogs (Montoya et al., 2004; Mahmood and Ashraf, 2010) and humans (Busch et al., 1998).

Overexpression of epidermal growth factor receptor (EGFR) and HER-1/ErbB1 are associated with several malignancies in human and animals (Modijtahedi and Dean 1994). EGFR tyrosine kinase (TK) can be considered as an important target for therapeutic intervention in various tumors (Lei et al., 1999). Erlotinib is a potent selective inhibitor of the EGFR tyrosine kinase (TK) to treat patients with non-small cell lung cancer.

Drug like metformin that inhibiting mTOR through AMP activated protein kinase (AMPK) pathway has been proposed as a promising agent for cancer patient having diabetes as it increase survival rate of cancer patients (Issam et al., 2010; Sahra et al., 2011; Bhalla et al., 2012). Mazzone et al., (2010) also documented that diabetic patients with lung cancer who are previously exposed to metformin are less likely to present with metastatic disease and may survive longer. Therefore, a combination of meloxicam, erlotonib and metformin may be promising chemopreventive strategy in diabetes patients with cancer.

Combination therapy may lead to pharmacokinetic interaction which can produce unwanted therapeutic outcome. The pharmacokinetic interaction of meloxicam with methotrexate has been evaluated in patient with rheumatoid arthritis (Hubner et al., 1997). Similarly, pharmacokinetic interaction of meloxicam with warfarin has been reported in healthy male volunteers (Turck et al., 1997). Sadariya et al., (2010) investigated pharmacokinetic interaction of moxifloxacin and meloxicam in rats. Pharmacokinetic interaction of meloxicam with erlotinib and metformin has not been evaluated so far. The severe combined immunodeficient (SCID) mice is considered one of the worthy laboratory animal model used for research in the field of oncology. Looking to these fact, the present study was planned to study the impact of administration of erlotiniband metformin on pharmacokinetic profile of meloxicam in male SCID mice.

\section{Materials and Methods}

\section{Experimental animals and conditions}

Total of ninety six severe combined immunodeficient (SCID) male mice of 5-8 weeks of age were used to conduct the study which were obtained from in-house breeding stock as well as maintained at Animal Research Facility, Zydus Research Centre, Cadila Healthcare Ltd, Ahmedabad, India. Sterilized conventional polypropylene cages in animal isolators were used to house all mice in groups of 3 mice. Sterilized corncob was used as bedding material (changed twice a week) which was analysed for pesticide and microbial contaminants. The temperature and humidity in the experimental room were $22 \pm 3$ ${ }^{\circ} \mathrm{C}$ and $30-70 \%$, respectively. The light: dark cycle of 12:12 hours throughout the study period was followed. Gamma irradiated laboratory animal diet (Teklad 18, Rodent Pellet feed, Harlan laboratories, USA) and purified autoclaved drinking water ( $a d$ libitum) were provided to experimental animals. All necessary standard husbandry 
procedures were followed to provide stress free environment to animals and seven days acclimatization period was observed before experiment. Veterinary examination was performed before randomization and animals found healthy. The experimental protocol for general procedures and use of animals for conducting this study was approved by the Institutional Animal Ethics Committee (IAEC).

\section{Randomization and grouping of animals}

All animals were randomly assigned to four treatment groups as shown in Table 1. Each group consisting of total 24 mice, which were further randomly divided into 4 sub-groups (A, B, C and D) of 6 animals each. Total twelve blood sampling time points were distributed among the 4 sub-groups of 6 animals each (each animal/sub group was not bled more than three time points). The single time point concentration data set was made by clubbing and sequential arranging of all samples as per time points from different sub group. The same procedure of blood collection was repeated for other sub group of each treatment groups.

\section{Drugs and chemicals}

Erlotinib, meloxicam, metformin and tenoxicampure powder were obtained from Ms. Zydus Research Centre, Ahmedabad. Acetonitrile of HPLC grade was purchased from Merck India Ltd., Mumbai. Methanolwas procured from SD Fine Chemical Ltd., Mumbai. Twin-80 (polysorbate) was procured from Merck, Germany and hydroxylpropyl methylcellulose (HPMC) was procured from Colorcon Asia Pvt. Ltd.

\section{Administration of drugs and sampling}

Meloxicam, erlotinib and metformin were formulated in Tween 80 and in 2\% HPMC (prepared in purified water). The concentration strength of drug was adjusted with 2\% HPMC by keeping Tween 80 concentration at $0.25 \%$ in final formulation. Doses were calculated according to body weight of animals and administrated as per concentration strength of formulation. Meloxicam $(20 \mathrm{mg} / \mathrm{kg})$ was administered by intraperitoneal route with sterile $1 \mathrm{ml}$ tuberculin syringe and needle of $26 \mathrm{G}(0.45 \mathrm{~mm}$ x $13 \mathrm{~mm}$ ) whereas erlotinib $(30 \mathrm{mg} / \mathrm{kg}$ ) and metformin $(100 \mathrm{mg} / \mathrm{kg})$ were administered by oral route using oral gavage needle.

Blood samples $(0.25 \mathrm{ml})$ were collected from retro-orbital plexus under light anaesthesia in $0.5 \mathrm{ml}$ capacity centrifuge tube at 5, 10, 20, 40 minutes, 1, 2, 4, 6, 8, 12, 24 and 48 hours after administration of drug and/or combination of drugs. From each sub group, blood samples at 3 time points were collected. Blood samples were collected from all animals in heparinized tubes and centrifuged at $5000 \mathrm{rpm}$ for 10 minutes at ambient temperature to obtain plasma. Separated plasma was transferred to labelled cryovials and stored at $-70{ }^{\circ} \mathrm{C}$ until analysis of drug which was carried out usually within a week.

\section{Meloxicam Assay}

The plasma samples $(45 \mu \mathrm{L})$ were transferred in $2 \mathrm{ml}$ micro-centrifuge tube to which $5 \mu \mathrm{L}$ of working solution $(10 \mu \mathrm{g} / \mathrm{mL})$ of Tenoxicamas an internal standard and $50 \mu \mathrm{L}$ of $0.01 \% \mathrm{v} / \mathrm{v}$ formic acid in purified water were added to each sample. The contents were mixed by vortexing for 30 seconds. Conditioning of the cartridge (Strio-E, 30mg 1cc) was done by adding $1 \mathrm{~mL}$ methanol followed by $1 \mathrm{~mL}$ water. The samples were loaded in sequence of blank, zero samples, calibration standards, quality control samples and test samples. The cartridge was washed twice by adding $1 \mathrm{~mL}$ water. Samples were eluted in $1 \mathrm{ml}$ of extraction solvent $\{0.01 \%$ ammonium in 
water: Acetonitrile (20:80\% v/v) \}, which were vortexed and transferred into HPLC vials for analysis. Two $\mu \mathrm{L}$ was injected using auto sampler (SIL-HTcAutosampler, Shimadzu, Japan) in LC system (Shimadzu Corporation, Koyoto, Japan) with MS-Ms (API 3200 LCMS/Ms system, PE SCIEX, Canada). The temperature of auto sampler was $10^{\circ} \mathrm{C}$. ACE C18 (50 mm x $4.6 \mathrm{~mm}$ ), $5 \mu \mathrm{m}$ column was used for the separation of drug at ambient temperature $\left(25 \pm 5^{\circ} \mathrm{C}\right)$. Meloxicam eluted at $0.42 \pm 0.5$ minutes. Ions were generated using electrospray ionization and detected in the positive-ion mode. The mobile phase consisted $0.1 \%$ Ammonia in water (Solution A) and acetonitrile (Solution B). The mobile phase was pumped at the flow rate of 1.0 $\mathrm{ml} / \mathrm{min}$ (LC-20-AD, Prominence, Pump, and Shimadzu, Japan). Ion spray voltage and temperature in detector were $4500 \mathrm{~V}$ and 550 ${ }^{\circ} \mathrm{C}$, respectively. Dwell time was 300 Seconds.

The methodology was validated by spiking the mice plasma samples with known amounts of meloxicam. Accurately weighed $10 \mathrm{mg}$ of meloxicam pure API grade powder was dissolved in diluent (methanol: water in the ratio of $80: 20)$ to make the concentration of $1,000 \mu \mathrm{g} / \mathrm{mL}$ (Stock solution A). Similarly, $1.0 \mathrm{mg}$ of tenoxicam was dissolved in the diluents to make the concentration of 100 $\mu \mathrm{g} / \mathrm{mL}$ (Stock solution B). Working solutions for calibration standards and quality control (QC) samples of meloxicam were prepared from the stock solution A in the range of 1000 to $80,000 \mathrm{ng} / \mathrm{mL}$. Working solution of internal standard was prepared by diluting $0.8 \mathrm{~mL}$ of stock solution B up to $10.0 \mathrm{~mL}$ with diluent in volumetric flask to get final concentration of 8 $\mu \mathrm{g} / \mathrm{mL}$. Calibration samples consisted of eight different concentrations of erlotinibover the range of 1000 to $80,000 \mathrm{ng} / \mathrm{mLin}$ the diluents and plasma. The low, medium and high quality control samples $(1500,8000,80,000$ $\mathrm{ng} / \mathrm{mL}$ ) were prepared independently in diluent and plasma. All QC samples in the plasma were treated similar to the method described above. The mean recovery of meloxicam from the plasma was $\geq 85 \%$ at $100 \mathrm{ng} / \mathrm{mL}$ (LLOQ). The linearity was observed from 1000 to $80,000 \mathrm{ng} / \mathrm{mL}$ with mean correlation coefficient $\left(\mathrm{R}^{2}\right)$ of 0.9985 . Intra-day and inter-day precision $( \pm 15 \%)$ and accuracy $( \pm 10 \%)$ were within standard limits. Validation parameters indicated that the method was reliable, reproducible and accurate.

\section{Pharmacokinetic and statistical analysis}

Various pharmacokinetic parameters were determined using WinNonlin software (version 5.2.1, Pharsight Corporation, USA) by non-compartmental analysis. The data obtained for pharmacokinetic parameters were presented as Mean \pm SEM and analysed statistically using unpaired two tail ' $t$ ' test. Where $\mathrm{p} \leq 0.05$ was considered as statistically significant and $\mathrm{p} \leq 0.01$ was considered as statistically highly significant.

\section{Results and Discussion}

In the present study, the meloxicam in plasma was detected in samples collected up to $24 \mathrm{~h}$ in animals of all groups. Semi-logarithmic plot of plasma meloxicam concentration following single dose administration alone, in combination with erlotinib and/or metformin are graphically presented in Figure 1. Pharmacokinetic parameters calculated from plasma concentration-time profile after single dose administration of meloxicam alone and in combination with erlotinib and/or metformin in male SCID mice are depicted in Table 2. MEX: Meloxicam; ERT: Erlotinib; MET: Metformin; $\mathrm{T}_{\max }$ : Time of maximum drug concentration; $\mathrm{C}_{\max }$ : Maximum drug concentration; $\mathrm{T}_{1 / 2}$ : Elimination half-life; AUC $_{(0-\infty)}$ : Area under the curve from zero to infinity; Vz: Volume of distribution; $\mathrm{Cl}$ : Total body clearance; MRT: Mean residence time. 
Table.1 Experimental outline showing animal number and data set number for Various treatment groups

\begin{tabular}{|c|c|c|c|c|}
\hline $\begin{array}{c}\text { Group } \\
\text { No. }\end{array}$ & Treatment Group & $\begin{array}{c}\text { Cage } \\
\text { No. }\end{array}$ & $\begin{array}{c}\text { Animal } \\
\text { No. }\end{array}$ & $\begin{array}{c}\text { Data } \\
\text { Set No. }\end{array}$ \\
\hline I & Meloxicam & $1-8$ & $1-24$ & $1-6$ \\
\hline II & Meloxicam + Erlotinin & $9-16$ & $25-48$ & $7-12$ \\
\hline III & Meloxicam + Metformin & $17-24$ & $49-72$ & $13-18$ \\
\hline IV & Meloxicam +Erlotinin + Metformin & $25-32$ & $73-96$ & $19-24$ \\
\hline
\end{tabular}

Final data set was prepared for six animals by pooling data of sub groups.

Table.2 Pharmacokinetic (PK) parameters of meloxicam following single dose administration $(20 \mathrm{mg} / \mathrm{kg}$, i.p) alone in combination with erlotinib $(30 \mathrm{mg} / \mathrm{kg}, \mathrm{p} . \mathrm{o})$ and/or metformin (100 mg/kg, p.o) in male SCID mice

\begin{tabular}{|c|c|c|c|c|}
\hline PK parameters & MEX & MEX + ERT & MEX + MET & MEX+ERT+ MET \\
\hline $\mathbf{T}_{\max }(\mathbf{h})$ & $0.40 \pm 0.09$ & $0.33 \pm 0.00$ & $0.39 \pm 0.06$ & $0.33 \pm 0.00$ \\
\hline $\mathrm{C}_{\max }(\mathrm{ng} / \mathrm{mL})$ & $45715.22 \pm 3343.07$ & $49994.17 \pm 2928.14$ & $46725.46 \pm 3798.13$ & $39648.95 \pm 2190.41$ \\
\hline$T_{1 / 2}(h)$ & $3.79 \pm 0.34$ & $3.51 \pm 0.37$ & $4.66 \pm 0.30$ & $4.10 \pm 0.40$ \\
\hline $\mathrm{AUC}_{(0-\infty)}(\mathrm{ng} \cdot \mathrm{h} / \mathrm{mL})$ & $123999.94 \pm 4181.79$ & $196948.88 \pm 6206.02 * *$ & $113819.23 \pm 1751.21$ & $137189.18 \pm 2845.93$ \\
\hline $\mathrm{Vz}(\mathrm{mL})$ & $873.90 \pm 59.61$ & $524.79 \pm 75.33^{*}$ & $1184.20 \pm 87.65^{*}$ & $858.22 \pm 69.29$ \\
\hline $\mathrm{Cl}(\mathrm{mL} / \mathrm{h})$ & $162.24 \pm 5.67$ & $102.10 \pm 3.52 * *$ & $175.92 \pm 2.66$ & $146.10 \pm 3.02 *$ \\
\hline MRT (h) & $3.32 \pm 0.15$ & $4.33 \pm 0.19 * *$ & $3.80 \pm 0.08$ & $3.51 \pm 0.27$ \\
\hline
\end{tabular}

$*$ Significant at $\mathrm{p}<0.05, * *$ Significant at $\mathrm{p}<0.01$

Fig.1 Semi logarithmic plot of meloxicam plasma concentration following single dose administration (20 mg/kg, i.p) alone and combination with erlotinib (30 mg/kg, p.o), and/or metformin $(100 \mathrm{mg} / \mathrm{kg}, \mathrm{p} . \mathrm{o})$ in male SCID mice

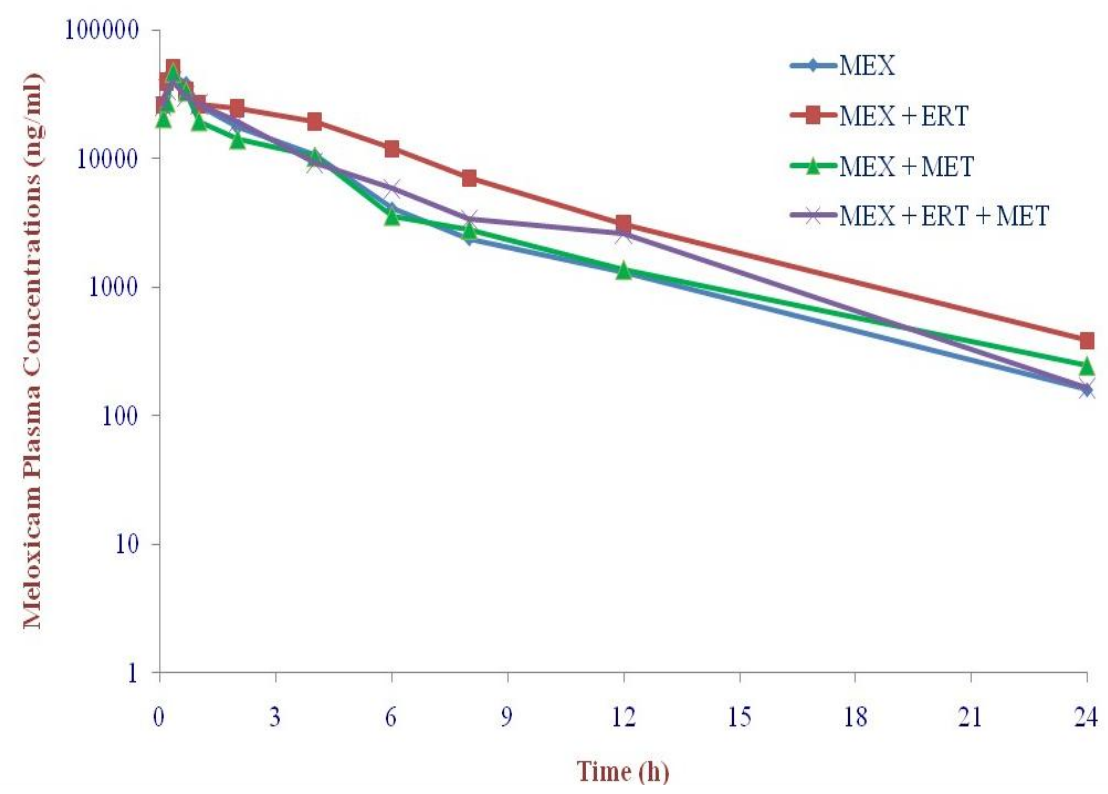


Combination therapy in complicated disease condition may lead to produce unpredictable therapeutic outcome due to their interaction. Non-steroidal anti-inflammatory drugs (NSAIDs) are frequently recommended with antineoplastic drugs to treat carcinogenic condition accompanied by pain and other inflammatory conditions. At old age, carcinogenic conditions (NSCLC) are mainly observed with complicated condition like metabolic disorders (i.e. diabetes). To treat such complicated conditions, drug therapy with EGFR inhibitors, COX-2 inhibitors as well as mTOR inhibitors may be used to produce relief from symptoms. Looking to the application of such combination therapy, the study was planned to evaluate impact of erlotiniband metformin administration on pharmacokinetics of meloxicam in SCID mice.

Following intraperitoneal administration of meloxicam as single drug in male SCID mice, the mean peak plasma level of drug was observed $44858.46 \pm 3486.54 \mathrm{ng} / \mathrm{mL}$ at 0.33 $\mathrm{h}$, which slowly declined to $10660.24 \pm$ $381.76 \mathrm{ng} / \mathrm{mLat} 4 \mathrm{~h}$ and thereafter the drug concentration in plasma diminished slowly and was detectable $(160.24 \pm 9.75 \mathrm{ng} / \mathrm{mL})$ up to $24 \mathrm{~h}$. The mean plasma concentration of meloxicam was found significantly higher when administered with erlotinib at $2 \mathrm{~h}, 4 \mathrm{~h}$, $6 \mathrm{~h}, 8 \mathrm{~h}, 12 \mathrm{~h}$ and in combination with all three drugs at $12 \mathrm{~h}$ post administration. Higher plasma concentration of meloxicam may probably due to inhibition of CYP2C9, enzyme responsible for meloxicam metabolism. Haouala et al., (2011) reported increased concentration of ibuprofen, mefenacid, metamizole and diclofenac in human when co administered with tyrosine kinase inhibitors.

Following intraperitoneal administration of meloxicam alone in male SCID mice, calculated $t_{\max }$, calculated $\mathrm{C}_{\max }, \mathrm{t}_{1 / 2}, \mathrm{~V}_{\mathrm{z}}, \mathrm{AUC}_{0-}$ $\infty, \mathrm{Cl}$, and MRT of meloxicam were $0.40 \pm$ $0.09 \mathrm{~h}, 45715.22 \pm 3343.07 \mathrm{ng} / \mathrm{mL}, 3.79 \pm$ 0.34 h, $123999.94 \pm 4181.79$ ng.h/mL, 873.90 $\pm 59.61 \mathrm{ml}, 162.24 \pm 5.67 \mathrm{ml} / \mathrm{h}$ and $3.32 \pm$ $0.15 \mathrm{~h}$, respectively.

Following intraperitoneal administration of meloxicam in combination with erlotinib in male SCID mice, the mean $\mathrm{AUC}_{0-\infty}$ was significantly $(\mathrm{p}<0.01)$ high compared to $\mathrm{AUC}_{0-\infty}$ of meloxicam alone treated animals which indicates vast area of body is covered by meloxicam concentration. This significant change in $\mathrm{AUC}_{0-\infty}$ can be correlated with other pharmacokinetic parameter like $\mathrm{C}_{\max }$, volume of distribution, clearance and MRT. The mean $\mathrm{Vd}$ of meloxicam was found to be significantly $(p<0.05)$ low compared that observed in meloxicam alone treatment group which may be due to increase in microcirculation in organs by metformin (Scarpello and Howlett, 2008). The mean total body clearance $(\mathrm{Cl})$ was found significantly low $(\mathrm{p}$ $<0.01)$ compared to that of meloxicam alone treatment group. The mean value of MRT of drug was significantly $(\mathrm{p}<0.05)$ higher compared to MRT of meloxicam alone treatment group. The decrease in clearance of meloxicam when given in combination with erlotinib might be due to the extensive metabolism of both the drugs by liver as explained by Busch et al., (1998) and Li et al., $\left(2007^{\mathrm{a}}\right)$ as well as the enzyme involved in metabolism of both drugs like CYP3A4, CYP3A5, CYP1A1, CYP1A2 and CYP2C9 as reported by Meineke and Turck (2003) and Li et al., $\left(2007^{\mathrm{b}}\right)$. It is also reported by Busch et al., (1998) that 60-65 \% metabolite of meloxicam are being excreted through kidney whereas meloxicam may decrease the blood flow to kidney (Horl, 2010), which may be the reason of low clearance rate. The smaller value of volume of distribution in present study is typical of the class NSAIDs which may be due to higher plasma protein biding of meloxicam (Turck et al., 1996). 
Following intraperitoneal administration of meloxicam in combination with metformin in male SCID mice, the mean $\mathrm{V}_{\mathrm{z}}$ of meloxicam was significantly higher $(p<0.05)$ compared to meloxicam given alone. Following intraperitoneal administration of meloxicam in combination with erlotinib and metformin in male SCID mice, significant $(p<0.05)$ decrease in mean $\mathrm{Cl}$ of meloxicam was observed as compared to $\mathrm{Cl}$ found in meloxicam alone treatment group.

It was concluded that administration of erlotiniband metformin in combination with meloxicam altered pharmacokinetic profile of meloxicam in SCID mice. However, concomitant use of these drugs for prolong period requires close clinical therapeutic evaluation for potential pharmacokinetic drug interaction.

\section{Acknowledgments}

We thank Mr. Pankaj R. Patel, CMD of Zydus Cadila Healthcare Ltd, Ahmedabad, India for providing the laboratory facility to carry out the research work. We are also thankful to Mr. Harilal Patel, Dr. Pradhyuman Gohil and Mr. Bharat Patel for their technical support.

\section{References}

Abou-Issa, H. M., Alshafie, G. A., Seibert, K., Koki, A. T., Masferrer, J. L and Harris, R. E. 2001. Dose-response effects of the COX-2 inhibitor, celecoxib, on the chemoprevention of mammary carcinogenesis. Anticancer Research. 21: 3425-3432.

Aguilar-Mariscal, H., Patino-Camacho, S, I., Rodriguez-Silverio, J., Torres-Lopez, J, E, and Flores-Murrieta, F. J. 2007. Oral pharmacokinetics of meloxicam in the rat using a high-performance liquid chromatographic method in microwhole blood samples. Experimental
Clinical Pharmacology. 29(9): 587.

Bhalla, K., Hwang, B. J., Dewi, R. E., Twaddel, W., Goloubeva, O. G., Wong, K. K., Saxena, N. K., Biswal, S., Girnun, G. D (2012). Metformin prevents liver tumorigenesis by inhibiting pathways driving hepatic lipogenesis. Cancer Prevention Research. 5(4):544-52.

Busch, U., Schmid, J., Heinzel, G., Schmaus, H., Baierl, J., Huber, C and Roth, W. 1998. Pharmacokinetics of meloxicam in animals and the relevance to humans. Drug Metabolism and Disposition. 26: 576-584.

Carpenter, J. W., Pollock, C. G., Koch, D. E. and Hunter, R. P. 2009. Single and Multiple-Dose Pharmacokinetics of Meloxicam after Oral Administration to the Rabbit (Oryctolagus cuniculus). Journal of Zoo and Wildlife Medicine. 40(4): 601-606.

Friton, G. M., Philipp, H., Schneider, T and Kleemann, R. 2003. Berliner Und Munchener Tierarztliche Wochenschrift. 116: 421-426.

Giardiello, F.M. 1996. NSAID-induced polyp regression in familial adenomatous polyposis patients. Gastroenterology Clinical of North America.25: 349-362.

Goldman, A. P., Williams, C. S., Sheng, H., Lamps, L. W., Williams, V. P., Pairet, M., Morrow, J. D and DuBois, R. N. 1998. Meloxicam inhibits the growth of colorectal cancer cells. Carcinogenesis. 19(12): 2195-2199.

Habashi, A. A. and Jamali, F. 2008. Pharmacokinetics of Meloxicam Administered as Regular and Fast Dissolving Formulations to the Rat: Influence of gastrointestinal dysfunction on the relative bioavailability of two formulations. European Journal of Pharmaceutics and Biopharmaceutics. 70(3):889-94

Haouala, A., Widmer, N., Duchosal, M. A., 
Montemurro, M., Buclin, $\mathrm{T}$ and Decosterd, L. A. 2011. Drug interactions with the tyrosine kinase inhibitors imatinib, dasatinib, and nilotinib. Blood. 117(8): e75-e87.

Hirsch, A. C., Philipp, $\mathrm{H}$ and Kleemann, R. 2003. Investigation on the efficacy of meloxicam in sows with mastitismetritis-agalactia syndrome. Journal of Veterinary Pharmacology and Therapeutics. 26:355-360.

Horl, W. H (2010). Nonsteroidal AntiInflammatory Drugs and the Kidney. Pharmaceuticals. 3:2291-2321.

Hubner, G., Sander, O., Degner, F. L., Turck, D and Rau, R. 1997. Lack of pharmacokinetic interaction of meloxicam with methotrexate in patients with rheumatoid arthritis. Journal of Rheumatology. 24(5):845-51.

Husain, S. S., Szabo, I. L and Tamawski, A. S. 2002. NSAID inhibition of GI cancer growth: clinical implications and molecular mechanisms of action. American Journal of Gastroenterology.97:542-553.

Issam, B. S., Yannick, L. M., Jean-François, $\mathrm{T}$ and Frederic, B. 2010. Metformin in Cancer Therapy: A New Perspective for an Old Antidiabetic Drug. Molecular and Cancer Therapeutics. 9(5):1092 1099.

Lei, W., Mayotte, J. E and Levitt, M. L. 1999. Enhancement of chemo sensitivity and programmed cell death by tyrosine kinase inhibitors correlates with EGFR expression in non-small cell lung cancer cells. Anticancer Research. 19:221-228.

Li, F., Kulkarni, A., Pauletti, G and Desai, P. $2007^{\mathrm{b}}$. Influence of BAS 100, a spiroortho-ester, isolated from grapefruit juice on the activity and expression of drug metabolizing enzymes and transporters. AAPS J. 9(2): 3402.

Li, J., Zhao, M., He, P., Hidalgo, $M$ and Baker, S. D. 2007 . Differential metabolism of gefitinib and erlotinib by human cytochrome P450 enzymes. Clinical Cancer Research.13:37313737.

Mahmood, K. T. and Ashraf, M. 2010. Pharmacokinetics of meloxicam in healthy dogs. Pakistan Veterinary Journal. 30:1-4

Mazzone, P. J., Rai, H. S., Beukemann, M., Meng, X., Abdallah, R and Sasidhar, M 2010.The effect of metformin and thiazolidinedione use on lung cancer. Chest. 138:882.

Meineke, I and Turck, D. 2003. Metformin therapy and clinical uses. British Journal of Clinical Pharmacology. 55(1):32.

Modijtahedi, H and Dean, C. 1994. The receptor for EGF and its ligands: Expression, prognostic value and target for therapy in cancer. International Journal of Oncology. 4: 277-296.

Montoya, L., Ambros, L., Kreil, V., Bonafine, R., Albarellos, G., Hallu, R and Soraci, A. 2004. A pharmacokinetic comparison of meloxicam and ketoprofen following oral administration to healthy dogs. Veterinary Research Communicus. 28:415-428.

Papatsas, I., Georgoulakis, I. E., Filiousis, G., Alexopoulos, G and Kyriakis, S. C. 2004. Meloxicam: A Literature review. Dopharma Research. pp 1-13.

Ramalingam, S and Belani, C.P. 2004. Cyclooxygenase-2 inhibitors in lung cancer. Clinical Lung Cancer. 5(4): 245-253.

Ristimaki, A., Nieminen, O., Saukkonen, K., Hotakainen, K., Nordiling, S. and Haglund, C. 2001. Expression of cyclooxygenase-2 in human transitional cell carcinoma of the urinary bladder. American Journal of Pathology.158: 849-53.

Sadariya, K. A., Gothi, A. K., Patel, S. D., 
Patel, H. V., Bhavsar, S. K. and Thaker, A. M. 2010. Pharmacokinetic interaction of moxifloxacin and meloxicam following intramuscular administration in rats. Pharma Science Monitor. 1: 1-5.

Sahra, I. B., Yannick, L. M., Jean-Francois, T. and Frederic, B. 2010. Metformin in Cancer Therapy: A New Perspective for an Old Antidiabetic Drug. Molecular and Cancer Therapy. 9(5): 1092-1099.

Scarpello, J. H. and Howlett, H. C. 2008. Metformin therapy and clinical uses. Diabetesand Vascular Disease Research. 5(3): 157-167.

Steinbach, G., Lynch, P.M., Phillips, R.K.S., Wallace, M.H., Hawk, E., Gordon, G.B., Wakabayashi, N., Saunders, B., Shen, Y., Fujimura, T., Su, L.K., Levin, B., Godio, L., Patterson, S., RodriguezBigas, M.A., Jester, S.L., King, K.L., Schumacher, M., Abbruzzese, J., DuBois, R.N., Hittelman, W.N., Zimmerman, S., Sherman, J.W. and Kelloff, G. 2000. The effect of celecoxib, a cyclooxygenase-2 inhibitor, in familial adenomatous polyposis. New
England J Medicine.342: 1946-1952.

Suzuki, R., Yamamoto, M., Saka, H., Taniguchi, H., Shindoh, J., Tanikawa, Y., Nomura, F., Gonda, H., Imaizumi, K., Hasegawa, Y and Shimokata, K. 2009. A phase II study of carboplatin and paclitaxel with meloxicam. Lung Cancer. 63(1): 72-76.

Thun, M. J. 1996. NSAID use and decreased risk of gastrointestinal cancers. Gastroenterology of Clinical of North America.25: 333-348.

Turck, D., Roth, W. and Busch, U. 1996. A review of the clinical pharmacokinetics of meloxicam. British Journal of Rheumatology. 35(1):13-16.

Turck, D., Su, C., Heinzel, G., Busch, U., Bluhmki, E. and Hoffmann, J. 1997. Lack of interaction between meloxicam and warfarin in healthy volunteers. European Journal of Clinical Pharmacology. 51:421- 425.

Turner, P. V., Chen, H. C. and Taylor, W. M. 2006. Pharmacokinetics of meloxicam in rabbits after single and repeat oral dosing. Comparative Medicine. 56:6367.

\section{How to cite this article:}

Patel, S.D., U.D. Patel, K.A. Sadariya, S.K. Bhavsar and Thaker, A.M. 2018. Impact of Erlotinib and Metformin Administration on Pharmacokinetics of Meloxicam in SCID Mice. Int.J.Curr.Microbiol.App.Sci. 7(03): 2252-2260. doi: https://doi.org/10.20546/ijcmas.2018.703.265 